\title{
A novel way to understand plant species preferences in relation to groundwater discharge conditions using a trait-based approach
}

\author{
Yasmijn A. M. van der Knaap, ${ }^{1 *}$ Jacob C. Douma, ${ }^{2}$ Rien Aerts, ${ }^{1}$ Remco van $\mathrm{Ek}^{3}$ and \\ Peter M. van Bodegom ${ }^{1,4}$ \\ ${ }^{1}$ Systems Ecology, Department of Ecological Science, Faculty of Earth and Life Sciences, VU University Amsterdam, De Boelelaan 1085,1081 HV \\ Amsterdam, The Netherlands \\ ${ }^{2}$ Centre for Crop Systems Analysis, Wageningen University, Droevendaalsesteeg 1, 6708 PB Wageningen, The Netherlands \\ ${ }^{3}$ Deltares, Unit Subsurface and Groundwater Systems, Section Groundwater Management, PO Box 85467, 3508 AL Utrecht, The Netherlands \\ ${ }^{4}$ Center for Environmental Sciences CML, Leiden university, Einsteinweg 2, 2333 CC Leiden, The Netherlands
}

\begin{abstract}
Groundwater discharge sites harbour characteristic and often rare plant communities that differ substantially from groundwater recharge sites. It is not known which abiotic conditions at these sites drive the differences in community composition. A trait-based approach, which relates species traits to abiotic conditions, may provide insight in this relationship and improve conservation management of these characteristic communities. We used this approach to identify the following: (i) dominant abiotic conditions that shape plant communities at discharge sites and (ii) characteristic traits associated with these abiotic conditions. First, we performed a (qualitative) literature survey to relate plant traits to various abiotic conditions at discharge sites. Second, we performed a meta-analysis to quantitatively test the trait selection at discharge sites. For the meta-analysis, we compiled a species discharge preference database $(n=170)$, based on literature and field data. We performed linear regression to relate traits to species discharge preference. Only 5 out of the 11 traits tested (low leaf phosphorus content, high leaf N:P, low rate of clonal reproduction, low maximum height and high seed mass) were significantly related to discharge preference, while the explained variance was low $\left(R^{2}<0.09\right)$. Our results suggest the following: (i) Despite the inclusion of traits specifically related to prevailing local environmental conditions, beyond commonly applied traits, hardly any differences were revealed; this indicates a need for more comprehensive eco-physiological understanding (and information on the selection of combinations of traits). (ii) A trait-based approach may not be highly distinctive in environments differing in only a few specific characteristics. Copyright (C) 2015 John Wiley \& Sons, Ltd.
\end{abstract}

KEY WORDS canopy height; clonal growth; leaf phosphorus content; N:P ratio; nutrient availability; P availability; seed mass; seepage

Received 3 November 2014; Revised 1 June 2015; Accepted 1 June 2015

\section{INTRODUCTION}

Groundwater discharge sites are important in shaping the lowland environment. Groundwater discharge sites are characterized by an upwards groundwater flow, while groundwater recharge sites are characterized by a downward or infiltrating groundwater flow. Precipitation infiltrates at recharge sites and can discharge at terrestrial groundwater discharge sites. The water chemistry between

*Correspondence to: Yasmijn A. M. van der Knaap, Systems Ecology, Department of Ecological Science, Faculty of Earth and Life Sciences, VU University Amsterdam, De Boelelaan 1085, $1081 \mathrm{HV}$ Amsterdam, The Netherlands.

E-mail: y.a.m.vander.knaap@vu.nl these sites is very different and leads to different abiotic conditions. The plant communities at discharge sites contain characteristic and often rare plant species that are not present at groundwater recharge sites (Wassen et al., 1990; McNamara et al., 1992; Lucassen et al., 2006; Marini et al., 2008; Zimmer et al., 2013; Kuglerová et al., 2014) and in general have a higher species diversity (Wassen et al., 1990; McNamara et al., 1992; Zinko et al., 2005; Lucassen et al., 2006; Klove et al., 2011; Zimmer et al., 2013; Kuglerová et al., 2014). It is however not clear what ultimately causes these characteristic and rare plant species to be especially abundant at discharge sites. This asks for a better understanding of the prevailing abiotic conditions in relation to community assembly of these communities (of which many are protected in e.g. the European Habitat directive). 
Abiotic conditions at discharge sites depend on a number of factors (Klijn and Witte, 1999): (i) the abiotic conditions at the recharge site (where rainwater infiltrates), (ii) the chemistry of the subsurface where the water flows through before reaching the surface, (iii) the processes that take place during the residence time of the water in the soil, and (iv) the soil properties at the discharge site. Therefore, when water discharges at the soil surface, its chemistry commonly differs substantially from the water that infiltrated at the recharge site. Recharge and discharge sites therefore differ from each other in a number of abiotic conditions (Figure 1).

First, water temperature for example is more constant throughout the year at discharge sites than at recharge sites because it is fed by a constant water flow from temperaturebuffered deeper soil layers (Klijn and Witte, 1999; Kalbus et al., 2006, Klove et al., 2011). Water temperature at recharge sites varies on a daily basis because it is in close contact with the surrounding and fluctuating air temperature. Second, the variation in water availability is different; recharge sites depend on precipitation, which can be highly variable in space and time. Discharge sites on the other hand are fed by a constant seepage flow, providing water year round and allowing for relatively constant water availability (Giesler et al., 1998). This does not mean that recharge sites are necessarily dry, but its origin of water is different. For instance, in lowland areas with low drainage capacity or areas with a semi-permeable layer close to the soil surface, (fast) infiltration of rain water is hampered, creating high groundwater tables. Third, there are relatively high concentrations of $\mathrm{Ca}^{2+}, \mathrm{Na}^{2+}, \mathrm{Si}^{2+}$ and $\mathrm{Fe}^{2+}$ in discharging groundwater although not all solutes are always present at freshwater discharge sites. The high

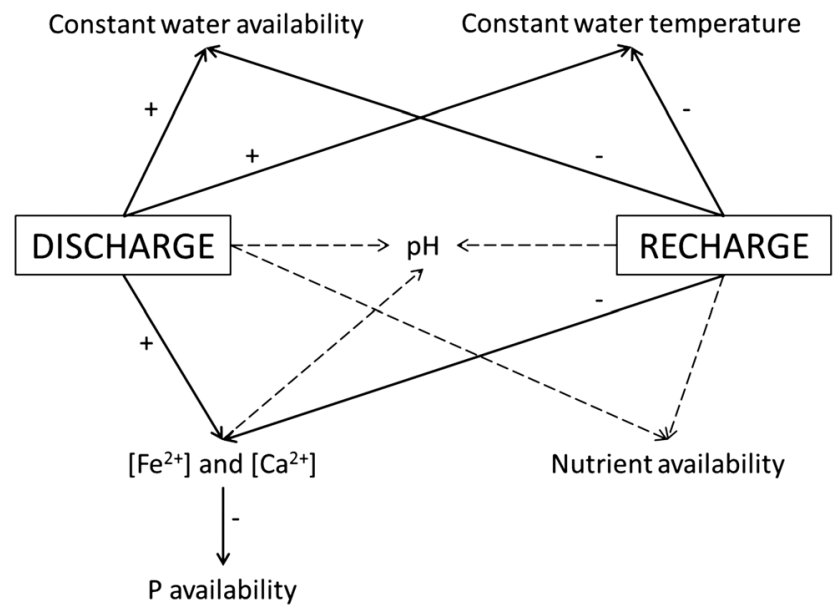

Figure 1. A schematic overview of abiotic differences between discharge and recharge sites in non-coastal areas. The '+' indicates a positive effect on the abiotic factor; the '-' indicates a negative relationship. Dashed lines show the abiotic conditions that do differ between discharge and recharge sites although the patterns are not uniform and depend on regional hydrogeological conditions. concentration of specific cations lowers phosphorus availability and influences soil $\mathrm{pH}$ (McNamara et al., 1992; Giesler et al., 1998; Klijn and Witte, 1999; Giesler et al., 2002; Tahvanainen, 2004; Lucassen et al., 2006; Zimmer et al., 2013). Also, the $\mathrm{pH}$ differs between the two site types although there are no uniform patterns (Giesler et al., 1998; Klijn and Witte, 1999; Tahvanainen, 2004; Zinko et al., 2006; Jansson et al., 2007; Zimmer et al., 2013; Kuglerová et al., 2014). Fourth, nutrient availability also differs between discharge and recharge sites, but there is no uniformity in where nutrient availability is highest as this depends on the regional geology (Giesler et al., 1998; Giesler et al., 2002; Lucassen et al., 2006; Jansson et al., 2007; Kuglerová et al., 2014).

Despite the known significance of, for example, variation in water availability (Leyer, 2005; Bartholomeus et al., 2011; Zou et al., 2014) or in nutrient availability (e.g. Ordoñez et al., 2010a; Douma et al., 2012a) as an important driver of plant species occurrences, it is not clear how these or other abiotic conditions select for a characteristic set of plant species that are constrained to, or prefer groundwater discharge sites.

One way to unravel this relationship is to focus on the relationship between abiotic conditions and the traits of plants that occur at these sites (Violle et al., 2007) as plant traits are directly linked to the abiotic environment. The abiotic conditions act as a filter that selects the species that have the appropriate traits for that environment (Keddy, 1992). Plant traits therefore offer a potential key to explain species occurrence differences between groundwater discharge and recharge sites, corresponding to the speciessorting paradigm of the metacommunity concept (Leibold et al., 2004). By connecting the abiotic conditions to plant traits, we can evaluate the following: (i) which traits are selected by the abiotic conditions affected by groundwater discharge and therefore (ii) which abiotic conditions have the strongest selection effect. This kind of information can guide water management in nature areas focusing on the protection of groundwater discharge dependent vegetation types.

We therefore aimed to unravel the driving abiotic conditions of vegetation communities at discharge sites by providing a general groundwater discharge-trait blueprint. We did this by two complementary approaches. First, we present a literature survey to describe the relationships between abiotic conditions at discharge sites and their potential effect on plant traits and to provide a summary on the current state of knowledge. Second, we compiled a database with characteristic plant species and their traits from discharge and recharge sites. We then analysed which plant traits differ between discharge and recharge species and to which abiotic conditions they relate. 


\section{REVIEW OF ABIOTIC CONDITIONS AND ASSOCIATED TRAITS AT DISCHARGE SITES}

On the basis of known relationships between abiotic conditions and plant traits and in light of the lack of studies that link abiotic conditions at discharge sites to plant traits, we selected the following abiotic conditions as potentially determining plant species distribution at groundwater discharge sites: nutrient availability, ferrous iron concentration and $\mathrm{P}$ availability (Table I). A number of other abiotic conditions that differ between discharge and recharge sites may also be essential for selecting plant species. However, we have not found studies that link these conditions to plant traits. These conditions are: constant water availability (i.e. little variation in water variability), water temperature and $\mathrm{pH}$. Differences in $\mathrm{pH}$ are generally considered to be linked to discharge patterns. Because $\mathrm{pH}$ effects are expressed both

Table I. Overview of the selected abiotic conditions, the associated traits and the relationship between the two as derived from literature data. The abiotic conditions are on the top row.

The indicated relationships were derived per trait from the references that are indicated in the footnotes.

\begin{tabular}{llll}
\hline Trait & Nutrient & Ferrous iron & P availability \\
\hline $\mathrm{SLA}^{\mathrm{a}, \mathrm{e}, \mathrm{o}, \mathrm{q}, \mathrm{r}}$ & + & & \\
$\mathrm{LNC}^{\mathrm{a}, \mathrm{l}, \mathrm{m}, \mathrm{p}, \mathrm{q}, \mathrm{r}}$ & + & & \\
$\mathrm{LS}^{\mathrm{e}, \mathrm{j}, \mathrm{k}}$ & + & & \\
$\mathrm{MaxCH}^{\mathrm{b}, \mathrm{e}, \mathrm{i}, \mathrm{j}, \mathrm{k}, \mathrm{s}}$ & + & & \\
$\mathrm{LPC}^{\mathrm{a}, \mathrm{l}, \mathrm{m} \mathrm{q}, \mathrm{r}}$ & + & & \\
$\mathrm{RGR}^{\mathrm{d}, \mathrm{h}, \mathrm{o}, \mathrm{r}}$ & + & - & - \\
$\mathrm{RP}^{\mathrm{c}, \mathrm{q}, \mathrm{r}}$ & & + & - \\
$\mathrm{FeTol}^{\mathrm{n}}$ & & + & - \\
$\mathrm{N}: \mathrm{P}^{\mathrm{a}, \mathrm{l}, \mathrm{m}, \mathrm{q}, \mathrm{r}}$ & & & \\
$\mathrm{SM}^{\mathrm{e}, \mathrm{g}}$ & & & \\
$\mathrm{LatSpread}^{\mathrm{f}}$ & & & \\
\hline
\end{tabular}

a van Bodegom and Heitman, unpublished data,

${ }^{\mathrm{b}}$ BioBase, 2003,

${ }^{c}$ Douma et al., 2012b,

${ }^{\mathrm{d}}$ Grime and Hunt, 1975,

${ }^{\mathrm{e}}$ Kleyer et al., 2008,

${ }^{\mathrm{f}}$ Klimešová and de Bello, 2009,

${ }^{g}$ Klotz et al., 2002,

${ }^{\mathrm{h}}$ Konings et al., 1989,

${ }^{i}$ Moles et al., 2004

${ }^{\mathrm{j}}$ Ordoñez et al., 2010b,

${ }^{\mathrm{k}}$ Ordoñez et al., 2010a,

${ }^{1}$ Reich and Oleksyn, 2004,

${ }^{\mathrm{m}}$ Roelofsen et al., 2014,

${ }^{\mathrm{n}}$ Snowden and Wheeler, 1993,

${ }^{\circ}$ Suter and Edwards, 2013,

${ }^{\mathrm{p}}$ Wright et al., 2004,

${ }^{\mathrm{q}}$ van der Knaap, Gardavska and Raschke, unpublished data,

${ }^{\mathrm{r}}$ Douma et al., 2012b,

s van Bodegom et al., unpublished data

'+' indicates a positive relationship, and '-' a negative one. SLA, specific leaf area; LNC, leaf nitrogen content; LS, leaf size; MaxCH, maximum canopy height; LPC, leaf phosphorus content; RGR, relative growth rate; $\mathrm{RP}$, root porosity; FeTol, iron sensitivity as \% of relative growth rate; N:P, leaf nitrogen to phosphorus ratio; SM, seed mass (with germinule); LatSpread, lateral spread (clonal reproduction). directly and indirectly, through the other chemical impacts mentioned (nutrient availability, ferrous iron concentration and $\mathrm{P}$ availability; Ponnamperuma, 1972), we will evaluate the impacts of those proximate drivers instead.

Because nutrient availability, ferrous iron concentration and $\mathrm{P}$ availability at a discharge site strongly depend on the geological setting (McNamara et al., 1992; Klijn and Witte, 1999; Giesler et al., 2002; Tahvanainen, 2004; Lucassen et al., 2006; Jansson et al., 2007), we selected data that refer to a specific region with relatively high data availability for the meta-analysis. This is the case for the (non-saline zones in the) Netherlands, which we therefore used as a case study area.

Groundwater discharge sites in the Netherlands are driven by the same abiotic conditions as other discharge sites (Figure 1), but the expression of those drivers can be different. Fe concentrations are generally high in the Netherlands, which relates to its geological subsurface, which enriches deep groundwater flows with $\mathrm{Fe}$. Because Fe binds phosphate, P availability for plants is low (Lucassen et al., 2006). Nitrate leaching from agricultural activities has initiated pollution of the groundwater and thus of groundwater discharge sites. Nevertheless, the relatively high $\mathrm{Ca}^{2+}$ concentrations in discharging groundwater can lower ammonium concentrations by binding stronger to the sediment than ammonium does. Ammonium, thus present in the pore water, can then be removed from the system by the flowing groundwater (Lucassen et al., 2006). Groundwater discharge sites in the Netherlands are therefore characterized by high Fe concentrations, low $\mathrm{P}$ availability and low nutrient availability.

\section{Nutrient availability}

Previous research has indicated a number of plant traits that are related to nutrient availability. More specifically, the traits that are part of the Leaf Economics Spectrum (LES, Wright et al., 2004) offer insight into potential differences in species characteristics for discharge or recharge sites. With these principles, we selected the following nutrient related leaf traits: specific leaf area (SLA, $\mathrm{mm}^{2} \mathrm{mg}^{-1}$ ), leaf nitrogen content (LNC, $\mathrm{mg} \mathrm{g}^{-1}$ ), leaf phosphorus content (LPC, $\mathrm{mg} \mathrm{g}^{-1}$ ) and leaf size (LS, $\mathrm{mm}^{2}$ ). Next to leaf traits we also selected maximum canopy height $(\mathrm{MaxCH}, \mathrm{m})$ and relative growth rate (RGR, $\mathrm{g}^{-1} \mathrm{~g}^{-1}$ day $^{-1}$ ). All these traits have been linked to nutrient availability in previous studies (Grime and Hunt, 1975; Poorter and Remkes, 1990; Lambers and Poorter, 1992; Wilson and Tilman, 1993; Cunningham et al., 1999; Knops and Reinhart, 2000; Ordoñez et al., 2009; Douma et al., 2012c). Given the lower nutrient availability at Dutch discharge sites, we expect species at discharge sites to be on the slow-return end of the LES spectrum, and we therefore expect SLA, LNC, LPC, LS, MaxCH and RGR all to be lower in plant species at discharge sites than at recharge sites. 


\section{Ferrous iron concentration}

High amounts of iron can be toxic to plants and constrain the growth rate of species at iron-rich sites (Snowden and Wheeler, 1993). Some plant species however can cope with these toxic values, which is reflected in the extent to which their growth rate is reduced under iron-rich conditions (Fe Tolerance; FeTol), as calculated by Snowden and Wheeler (1993). The higher the FeTol growth rate, the better a species can sustain its growth rate in iron-rich environments. These adaptations seem to imply a reduced maximum growth rate at non-stressful conditions (Snowden and Wheeler, 1993). Because the ferrous iron concentration is relatively high at groundwater discharge sites, we expect that because of this trade-off, plant species characteristic of discharge sites to have a low RGR. Among the adaptations of plant species to toxic iron concentrations is the capability to release oxygen from their roots to oxidize iron in the rhizosphere (Lamers et al., 2012). This influences rhizosphere $\mathrm{pH}$ and is a mechanism to reduce iron toxicity and lowers the impact of low redox conditions in general (Van Bodegom et al., 2008). Traits associated with this process are the occurrence of radial oxygen loss (ROL) and the capacity for convective flow and root porosity (RP). RP, the amount of aerenchyma tissue in a root (Colmer and Voesenek, 2009), allows for transport of oxygen from the shoot to the root. Consequently, species with a high RP are better capable of transporting oxygen to their roots from where it is partly released into the soil (Drew, 1990) and serves as a proxy of ROL. ROL is a process where oxygen diffuses from the root to the soil (Jackson and Armstrong, 1999) thereby oxidizing the environment and reducing iron toxicity. The higher the ROL, the lower the iron toxicity. Not only are species with a high RP more tolerant of high ferrous iron concentrations in anaerobic conditions (Snowden and Wheeler, 1993), RP also increases with higher ferrous iron concentrations in aerobic soils (Mongon et al., 2014), making it a highly susceptible trait to high iron concentrations. Finally, some species facilitate convective flows, which transports oxygen much faster than diffusive fluxes, through which even more oxygen can be translocated to the rhizosphere (Armstrong et al., 1996), reducing iron toxicity even further. Because the ferrous iron concentration is relatively high at discharge sites in the Netherlands, we expect a species' FeTol, RP, ROL and convective flow to be high and RGR to be low compared with recharge sites.

\section{$P$ availability}

While nutrient availability in general may be affected by groundwater discharge, $\mathrm{P}$ availability is particular negatively affected at discharge sites, leading to $\mathrm{P}$ limitation. $\mathrm{P}$ limitations are particularly reflected in the leaf $\mathrm{N}: \mathrm{P}$ ratio, which increases with increasing $\mathrm{P}$ limitation. Other traits can also directly be related to $\mathrm{P}$ availability. These include lifespan of a species (LSP) and leaf dry matter content (LDMC). Lifespan reflects a plant's strategy; it is either a fast grower with a short life cycle (annuals), or it has a low growth rate but a longer life cycle (perennials). A long lifespan is associated with a relatively low amount of available $P$ in the soil (Fujita et al., 2014). LDMC $\left(\mathrm{mg} \mathrm{g}^{-1}\right)$ reflects the average density of leaf tissue (Cornelissen et al., 2003). Plant species growing at P-limited sites have a higher LDMC (Fujita et al., 2014). Finally, a number of traits has been shown to relate specifically to $\mathrm{P}$ availability and include clonal reproduction (LatSpread) compared with seed production and seed mass (SM) (Dainese and Sitzia, 2013; Fujita et al., 2014). Plant species growing at low available $\mathrm{P}$ sites invest less in sexual reproduction and more in vegetative reproduction (Fujita et al., 2014), which may lead to an increase in the clonal reproduction. If a species reproduces by seed, then the SM of an individual seed is relatively high at P-limited sites (Dainese and Sitzia, 2013). Because $\mathrm{P}$ availability is low at groundwater discharge sites in the Netherlands, we expect that plant species' leaf N:P ratio, LSP, LDMC, LatSpread and SM will be relatively high compared with groundwater recharge sites.

\section{META-ANALYSIS OF DISCHARGE-TRAIT RELATIONSHIPS}

\section{Species}

The literature review provided us with qualitative insights on how traits might relate to groundwater discharge but no quantitative insights. To obtain a quantitative analysis, we performed a meta-analysis. For this meta-analysis, we selected plant species from the Netherlands that occur on groundwater discharge or recharge sites, based on literature and field data. We chose the Netherlands because of the following: (i) it has a large variety of recharge and discharge conditions, (ii) habitat preferences of most plant species are known and (iii) a comprehensive trait database was available. We used plant association literature and the ecotopes classification system (Whittaker et al., 1973) to identify species that are confined to, or more abundant, at groundwater discharge sites and species that are not (as explained later). To refine this species list, we removed any species that did not coincide with either discharge or recharge abiotic conditions, which included species that occur on a large abiotic gradient (e.g. in moist and dry ecosystems). Finally, we compared this species list with field observations to see if the species from literature actually match the ones found in the field. This further refined our selection and created a discharge preference list, which resulted in our final discharge-recharge species list (Appendix SI).

The literature on plant associations (sensu Schaminée et al., 1995a, 1995b; Schaminée et al., 1996; Schaminée et al., 1998; Weeda et al., 1999; Weeda et al., 2000, 2002, 
2003, 2005) helped to identify species that occur on groundwater discharge sites and those that occur on wet recharge sites. We excluded ecosystems with high salinity levels (e.g. coastal ecosystems). To make sure we selected only those species that are restricted to, or abundant at, discharge sites (or recharge sites), only the characteristic species (not the common ones) for that specific plant association, as indicated by literature, were selected. For every selected species, we checked whether this species was confined to groundwater discharge or recharge sites, based on additional literature (Van der Meijden, 1996). If it was, the species was put on the discharge-recharge species list. This list was checked by field experts.

Moreover, we used information provided through the ecotopes classification system, specified for the Netherlands (Runhaar et al., 2003), which is a classification system of plant communities based on vegetation structure and abiotic conditions. We selected ecotopes, which reflect abiotic conditions that are characteristic for groundwater discharge sites in the Netherlands (i.e. sites of wet, nutrient poor and weakly acid ecosystems). To select plant species that occur on recharge sites, we limited our search to wet ecosystems to reduce any confounding effects of water availability (i.e. excluding dry recharge sites). Although water availability is an important driver of plant species occurrence, it does not necessarily distinguish between recharge and discharge sites in the Netherlands.

By combining the two lists, we captured all characteristic species that occur on discharge sites based on literature and abiotic conditions. To limit confounding biotic and abiotic site effects, we applied additional filters. First, given that tree species are not necessarily bound to discharge sites and often lag behind the prevailing conditions, we selected only species that have belowground or soil surface perennating tissue, according to Raunkiær's classification (Raunkiær, 1934). That resulted in a selection of cryptophytes, chamaephytes and hemicryptophytes. Additionally, to rule out any effects of water availability, we filtered the data to represent wet sites only (Witte et al., 2007). We thus selected discharge species that occur on a moisture indicator gradient between 1.0 (aquatic) and 2.0 (moist), nutrient availability less than 1.5 (nutrient poor) and an acidity indicator value $>2.0$ (weakly acid-alkaline). For recharge species, we applied the same moisture filter, but we did not apply a nutrient and acidity filter. Our final literature-based discharge list contained 66 species, and our recharge list had 127 species on it.

\section{Field data on species occurrences}

To refine our binary classification of discharge and recharge species, we evaluated all selected species against a field observation database. This observation database contains field measurements of more than 34000 relevées in which species had been scored and classified to plant associations
(Landelijke Vegetatie Databank, The Netherlands). We compared our species list with the field observations and calculated the discharge preference (\%) of our species types (discharge or recharge) with the species types as found in the field. For example, if a species was classified as a discharge species based on the literature survey but it was never found in a discharge plant association in the field, it was given a discharge preference of $0 \%$. As a result of the high number of field observations, we improved the accurateness of the species distinction although the number of observations differed per species, ranging from 2 to 1472 . We used the species preference in our further analyses as dependent variable to test whether traits are related to species preference, thus achieving a more fine-tuned measure than the binary classification.

\section{Traits database}

Our discharge-recharge species list was coupled to a national trait database, based on numerous field studies (refer to Table I for references) to couple trait observations to species discharge preferences. From this database, we selected trait observations from wet habitats only because trait values of a species can differ between habitats (Cordlandwehr et al., 2013), which would potentially lead to biases. Next to habitat, we prioritized database entries on the basis of the protocol of trait measurements used, where consistent protocols were given priority, to ensure consistency among database entries. Finally, the database that had the highest number of data entries for a given trait was selected to minimize the effect of observer's bias and increase consistency between data entries. Prior to analysis, we selected only those traits that had a sufficient amount of entries for analysis $(n \geq 15)$. This resulted in the following 11 traits: SLA, LNC, MaxCH, LS, FeTol, RGR, RP, LPC, $\mathrm{N}: \mathrm{P}$, LatSpread and SM. The final dataset contained 170 species (61 discharge, 109 recharge) with at least one trait available. Additionally, we made a subset of our dataset in which we selected species that had a strong preference for either discharge or recharge sites (i.e. species with a discharge preference of $100 \%$ and $0 \%$, respectively). Because this severely reduced the number of available species (40 in total of which six discharge and 34 recharge species) and thereby data entries, we dropped seven traits that had fewer than 15 data entries. This subset consisted of MaxCH, LS, LatSpread and SM.

\section{Statistical analysis}

Prior to analysis, we log-transformed a number of traits (MaxCH, SM, LS, LPC, RGR, RP and SLA) to reduce the skewed distribution of the data. For models with FeTol, we log-transformed the species preference data to improve model fit. Because the species preference data also had 
zeroes (i.e. species that were only found at recharge sites, which thus have a $0 \%$ preference for discharge sites), we added +1 to all species preferences to enable the log transformation. For all traits, we performed a linear regression to test whether discharge preference is related to trait selection. We used a linear regression because we had no a priori information to fit non-linear relationships. We tested single-trait and two-trait combinations through single and multiple regression. Although we recognize the importance of multiple trait combinations improving the explanatory power of the model, we were unable to include more than two traits simultaneously because of a high number of missing data values, a common problem in database analyses (Kattge et al., 2011).

Additionally, we ran a binomial generalized linear model (GLM) where we divided the species between a discharge and recharge list, on the basis of the species preferences $(\geq 50 \%$ and $<50 \%$, respectively; Appendix SI), and tested whether we could distinguish between the two species types, on the basis of their trait values. The GLMs served as a check for the robustness of the linear regression analysis. We have also run a GLM while correcting for the phylogenetic relatedness of the species (Durka and Michalski, 2012) with a Generalized Estimating Equations (GEE). All analyses were performed with $R$ (R Core Team, 2012).

\section{RESULTS}

Five out of the 11 selected traits were significantly related to discharge species preferences although the explanatory power was very low $\left(R^{2}<0.09\right)$ (Figure 2$)$. The discharge preference was negatively correlated with LPC $(p=0.011$, $R^{2}=0.09$ ). A species' discharge preference was positively correlated with the N:P ratio $\left(p=0.031, R^{2}=0.06\right)$. The rate of clonal reproduction $\left(p=0.042, R^{2}=0.05\right)$ was negatively related to discharge preference. SM, on the other hand, was positively correlated with discharge preference $(p=0.036$, $R^{2}=0.03$ ). Finally, the maximum canopy height was negatively correlated with discharge preference $(p=0.030$, $R^{2}=0.03$ ). Summarizing, plant species at discharge sites have a relatively low LPC, high leaf N:P, low LatSpread, high SM and low MaxCH, compared with plant species at recharge sites. In our subset analysis of species with a high or low discharge preference, SM was the only trait that significantly differed between recharge and discharge species $\left(p=0.039, R^{2}=0.14\right)$.

In the multiple regression, two trait combinations were related to species' discharge preferences, being LatSpread and SM, and MaxCH and SLA. Discharge preference was positively correlated to $\mathrm{SM}$ and negatively correlated to rate of clonal reproduction $\left(R^{2}=0.11\right)$. Furthermore, discharge preferring species correlated positively with SLA and negatively with $\mathrm{MaxCH}\left(R^{2}=0.14\right)$.
From the GLM analysis, LatSpread $(p=0.019)$ and $\mathrm{MaxCH}(p=0.006)$ were significantly different between discharge and recharge species, where discharge species had lower LatSpread and MaxCH than recharge species (Figure 3; Appendix SII). The GLM analysis of the subset did not generate significant results. The GEE analysis, where we corrected for the phylogenetic relatedness, resulted in two significant traits: $\mathrm{MaxCH}(p=0.009)$ and $\mathrm{N}: \mathrm{P}$ $(p=0.004)$.

\section{DISCUSSION}

\section{A trait-based approach for community assembly at discharge sites}

With our trait-based approach, we highlighted a number of traits that are significantly related to the discharge preference of plant species in the Netherlands. The rate of clonal reproduction and maximum canopy height proved to be consistent traits, because both were significant in the single and multiple regression and GLM analyses. SM was significant in all regression analyses, while the N:P ratio was significant in both the regression analysis as well as in the GEE, where we corrected for phylogenetic relatedness of the species. Most of the significant traits showed the patterns that we expected, except for LatSpread and SLA. The rate of clonal reproduction was lower at discharge sites than at recharge sites, while we expected it to be higher, because vegetative reproduction is more common in $\mathrm{P}$ limited systems than sexual reproduction (Fujita et al., 2014). Nevertheless, although vegetative reproduction may be more common at discharge sites, this apparently does not imply that the rate of vegetative growth is also higher at discharge sites than at recharge sites. Furthermore, we expected discharge species to be on the slow-return end of the LES and thus have relatively low SLA. However, SLA was only significantly different between recharge and discharge species in combination with $\mathrm{MaxCH}$. Discharge species are thus apparently relatively small and have thin leaves. This may be explained by a relatively high amount of grass species or annuals at groundwater discharge sites, which coincides with this trait combination.

With a trait-based approach, a more mechanistic (and thus general) relationship between species and abiotic conditions may be derived. This allows to trace back which abiotic conditions affected by discharge are potentially dominant in the species-sorting paradigm of the metacommunity concept and thus shape the characteristic discharge plant communities. The significant traits from our analyses were related to $\mathrm{P}$ limitation $(\mathrm{N}: \mathrm{P}$, LatSpread and SM) and total nutrient availability (SLA, LPC and $\mathrm{MaxCH}$ ).

Surprisingly, traits related to ferrous iron were not related to the discharge preference of a species. However, the absence of this relationship may not be reliably interpreted to 

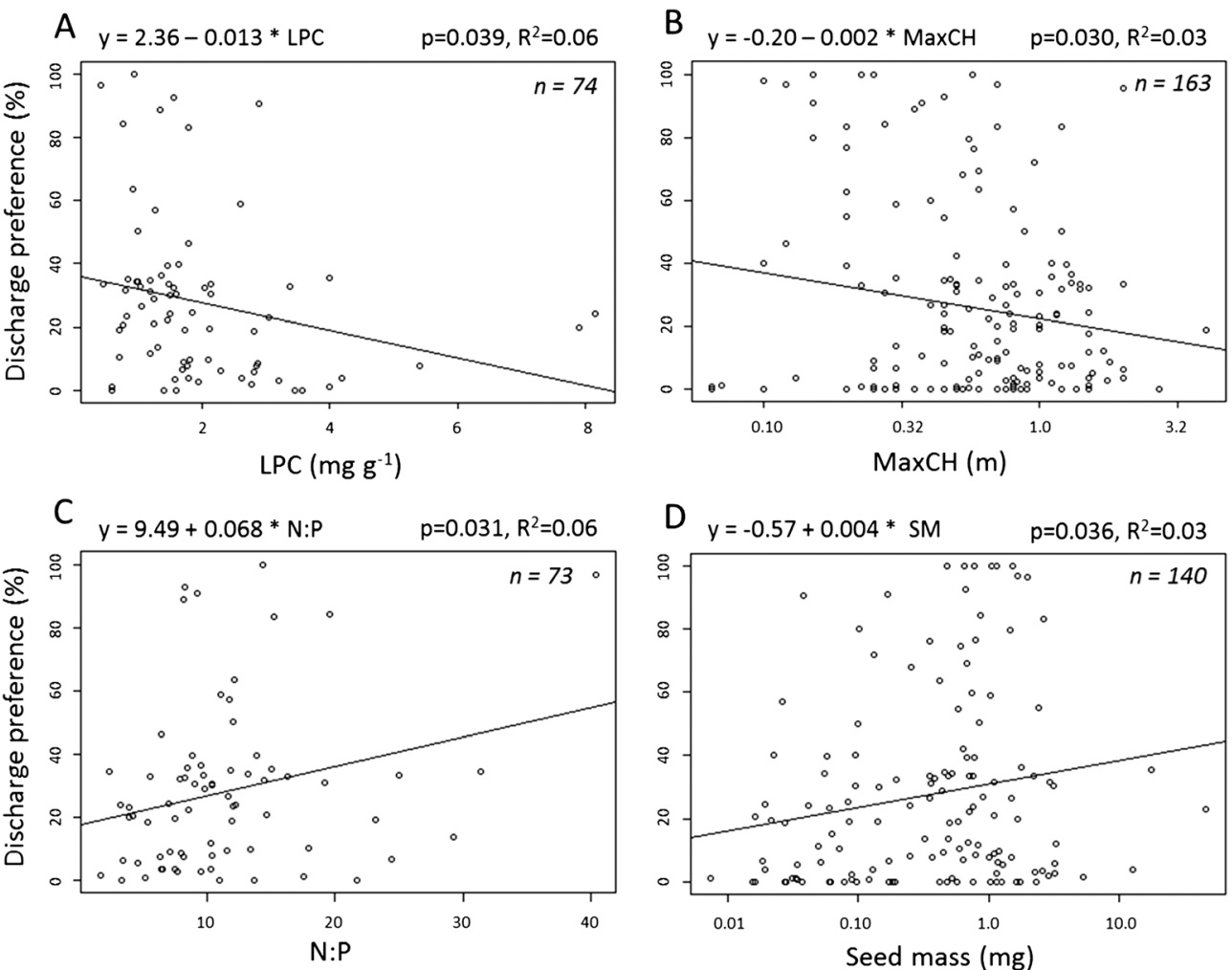

$\mathrm{E}$

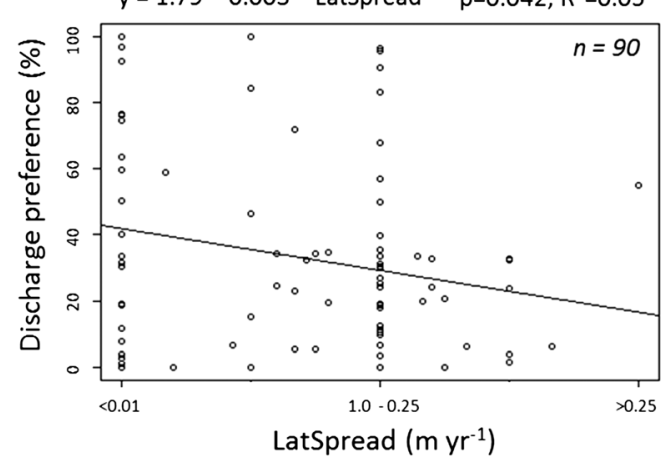

Figure 2. The significant models that are related to a species discharge/recharge preference. On the $y$-axis is the percentage that a species is found at a discharge site; $100 \%$ is only found at discharge sites, and $0 \%$ is only found at recharge sites. Every value in between is an indication of how often a species occurs at a discharge site. The regression model, significance level and associated $R^{2}$ are shown on the top of each graph. (A) The leaf phosphorus content, (B) the maximum canopy height, (C) the leaf nitrogen to phosphorus ratio, (D) seed mass and (E) the rate of clonal reproduction.
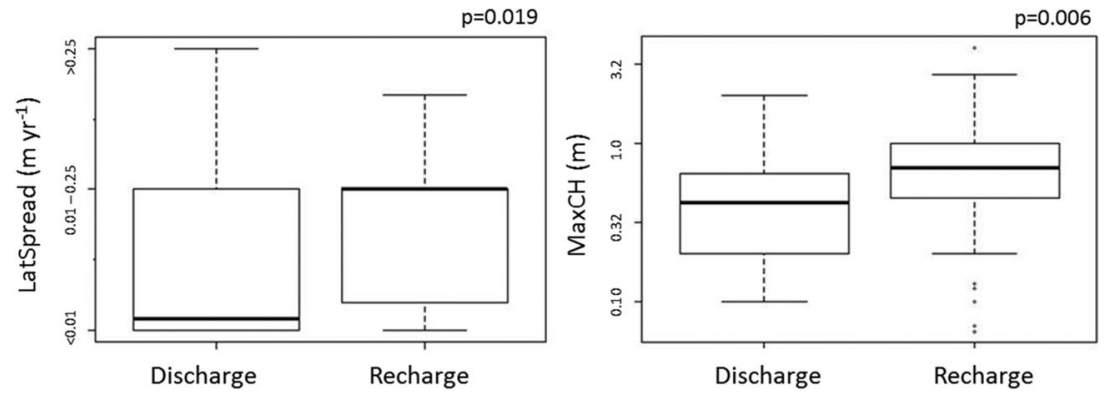

Figure 3. The two significant traits from the GLM analysis. The lateral spread is shown in the left boxplot and the maximum canopy height is shown on the right. 
indicate that it does not exist, given that we had fewer traits (RP, RGR and FeTol) each with fewer data entries related to ferrous iron concentration available. Interestingly, the explanatory power of our models was relatively high for $\mathrm{RP}$ and RGR although still low $\left(R^{2}=0.08\right)$. This may suggest that these traits have a better potential to predict discharge species occurrence especially because the $p$-value of these models suggested a trend $(p=0.067$ for RP and $p=0.095$ for RGR). It should be noted though that RGR is also related to nutrient availability (Grime and Hunt, 1975; Poorter and Remkes, 1990; Lambers and Poorter, 1992) and does not only represent the iron tolerance of a species

Together, our study shows that, in the non-coastal zone of the Netherlands and for the current sets of traits studied, the amount of available nutrients and phosphorus are important drivers distinguishing characteristic groundwater discharge plant communities from other wet communities. Although the significance of these abiotic conditions at groundwater discharge sites is not new, this is the first time that an effect for the associated traits of discharge versus recharge species is shown. These effects of nutrient-related traits on plant species of characteristic groundwater discharge communities partly relate to the lower nutrient availability at Dutch groundwater discharge sites compared with recharge sites. These nutrient conditions are caused by agricultural practices at recharge areas and the impact of groundwater discharge on $\mathrm{P}$ availability. On the other hand, at other discharge-recharge sites, the nutrient conditions are opposite of the Dutch situation (Giesler et al., 2002; Lucassen et al., 2006; Jansson et al., 2007; Kuglerová et al., 2014). This may imply that while nutrient availability will always be important to distinguish between species characteristic of recharge versus discharge sites, the actual direction of change may depend on the local landscape arrangements.

Low explanatory power of trait-based community assembly at discharge sites

Despite successful applications in previous studies at various scales (Douma et al., 2012a, 2012b; Stahl et al., 2013; Verheijen et al., 2013; Van Mechelen et al., 2014), our trait-based approach did not yield successful predictive results in our study. Discharge species are therefore hard to distinguish from recharge species with these traits, on the basis of the models we derived from our analyses. This low predictive ability may seem surprising given the wellestablished qualitative predictions and the fact that we aimed to include traits that go beyond the traits commonly measured and that are specifically related to environmental conditions occurring at discharge sites. This may suggest that differences in trait values between the discharge and recharge species may be too subtle to generate clear patterns (when database trait values are used). The ecosystems in our study are similar in climate and in one important abiotic condition that shapes plant communities - water availability. Perhaps the remaining environmental differences are too nuanced for a trait-based approach to be applicable. If that is the case, then the use of multiple abiotic drivers with their associated traits and, more importantly, the use of multiple traits combinations would be the way forward to gain explanatory power. Previous research has shown that especially the combinations of multiple traits, related to multiple abiotic conditions, are better predictors of vegetation patterns than individual traits (Ordoñez et al., 2010b; Douma et al., 2012c). In addition, multiple traits such as the Leaf Economic Spectrum (Wright et al., 2004) have been used to explain plant species strategies. Unfortunately, this was not possible in our analysis because of a high number of missing values. However, for the few combinations in which it was possible, a higher explanatory power was obtained.

In addition, we have seen in our data that the range of a selection of trait values is much larger for recharge preferring species than for discharge species (Figure 2, other data not shown). Although trait information is limited, our evidence suggests that discharge species have a smaller range of appropriate trait values, for some traits, than recharge species. This was for example the case for SM in our subset. All discharge species had a high SM, while the variation in the recharge species was much larger. This was also the case for LatSpread and $\mathrm{MaxCH}$, although to a lesser extent, but not for LS. This may suggest that recharge species have a wider niche space, which allows for more variation in a number of plant traits than for discharge species.

As such, biotic interactions may force discharge species to (the less favourable) discharge sites. Together, the evidence suggests that multiple abiotic conditions affected by groundwater discharge together shape the environmental pressures allowing the distinct (and nowadays rare) plant communities to prosper.

\section{Implications for trait-based approaches for evaluating local community assembly}

Our results point to a need for a much better understanding of trait selection acting at local scales, which may differ from traits and trait selection that differentiate species across large abiotic gradients. One of such traits could be seed germination in relation to temperature because soil temperature influences seed germination (Hoyle et al., 2013), where germination is lower at relatively cold soils than at warmer soils. Water temperature at discharge sites is constant and relatively low during the growing season compared with recharge sites. Species preferring discharge sites may thus need adaptations for seed germination at lower temperatures. In addition, lower temperature may also decrease oxygen demand (Bartholomeus et al., 2012), which may allow plants to use the limited amount of oxygen to deal with the high ferrous 
iron concentrations. This may be one of the variety of mechanisms and strategies (morphological, physiological and biochemical) of plants related to iron tolerance (Chabbi, 1999) although the exact plant controls are still unclear.

Next to the constant but lower water temperature, the constant water availability at discharge sites as opposed to more variable conditions at recharge sites may also result in different plant trait selection. Unfortunately, in studies empirically relating traits to environmental conditions, the variability in environmental conditions so far received little attention. The general understanding on differences in phenotypic plasticity among plant strategies, its impacts on trait selection in general and the interactions with dispersal capacity is still poor (Valladares et al., 2014).

Overall, this asks for a deeper understanding of plant ecophysiology and how plants respond to local abiotic conditions. Such understanding (made possible through field measurements and comprehensive trait databases for multiple species) will be essential for applying trait-based community assembly analyses to local specific communities. This can help improve our understanding of the functional differences in local plant communities in general and, in this case, at groundwater discharge and recharge sites in particular. Once the relevant trait selection processes are known, nature managers can maintain these abiotic conditions to maintain the rare and characteristic vegetation communities of groundwater discharge sites.

\section{ACKNOWLEDGEMENTS}

We thank Lieneke Verheijen for her help with writing the $R$-scripts. Flip Witte, Han Runhaar and Martin de Haan were very helpful in providing valuable advice regarding the recharge and discharge species list. Two anonymous reviewers provided valuable comments that greatly improved our manuscript. This project was funded by the Knowledge for Climate programme, Theme 3 (www. knowledgeforclimate.org).

\section{REFERENCES}

Armstrong W, Armstrong J, Beckett PM. 1996. Pressurised aeration in wetland macrophytes: some theoretical aspects of humidity-induced convection and thermal transpiration. Folia Geobotanica \& Phytotaxonomica 31: 25-36.

Bartholomeus RP, Witte J-PM, van Bodegom PM, van Dam JC, Aerts R. 2011. Climate change threatens endangered plant species by stronger and interacting water-related stresses. Journal of Geophysical Research 116: G04023.

Bartholomeus RP, Witte J-PM, van Bodegom PM, van Dam JC, de Becker P, Aerts R. 2012. Process-based proxy of oxygen stress surpasses indirect ones in predicting vegetation characteristics. Ecohydrology 5: 746-758.

BioBase. 2003. Centraal Bureau voor de Statistiek: Voorburg/Heerlen.

Chabbi A. 1999. Juncus bulbosus as a pioneer species in acidic lignite mining lakes: interactions, mechanism and survival strategies. New Phytologist 144: 133-142.
Colmer TD, Voesenek LACJ. 2009. Flooding tolerance: suites of plant traits in variable environments. Functional Plant Biology 36: 665-681.

Cordlandwehr V, Meredith RL, Ozinga WA, Bekker RM, van Groenendael JM, Bakker JP. 2013. Do plant traits retrieved from a database accurately predict on-site measurements? Journal of Ecology 101: 662-670.

Cornelissen JHC, Lavorel S, Garnier E, Diaz S, Buchmann N, Gurvich DE, Reich PB, ter Steege H, Morgan HD, van der Heijden MGA, Pausas JG, Poorter H. 2003. A handbook of protocols for standardised and easy measurement of plant functional traits worldwide. Australian Journal of Botany 51: 335-380.

Cunningham SA, Summerhayes B, Westoby M. 1999. Evolutionary divergences in leaf structure and chemistry, comparing rainfall and soil nutrient gradients. Ecological Monographs 69: 569-588.

Dainese M, Sitzia T. 2013. Assessing the influence of environmental gradients on seed mass variation in mountain grasslands using a spatial phylogenetic filtering approach. Perspectives in Plant Ecology Evolution and Systematics 15: 12-19.

Douma JC, Aerts R, Witte JPM, Bekker RM, Kunzmann D, Metselaar K, van Bodegom PM. 2012a. A combination of functionally different plant traits provides a means to quantitatively predict a broad range of species assemblages in NW Europe. Ecography 35: 364-373.

Douma JC, Bardin V, Bartholomeus RP, van Bodegom PM. 2012b. Quantifying the functional responses of vegetation to drought and oxygen stress in temperate ecosystems. Functional Ecology 26: 1355-1365.

Douma JC, Shipley B, Witte JPM, Aerts R, van Bodegom PM. 2012c. Disturbance and resource availability act differently on the same suite of plant traits: revisiting assembly hypotheses. Ecology 93: 825-835.

Drew MC. 1990. Sensing soil oxygen. Plant, Cell and Environment 13: 681-693.

Durka W, Michalski SG. 2012. Daphne: a dated phylogeny of a large European flora for phylogenetically informed ecological analyses. Ecology 93: 2297-2297.

Fujita Y, Venterink HO, van Bodegom PM, Douma JC, Heil GW, Holzel N, Jablonska E, Kotowski W, Okruszko T, Pawlikowski P, de Ruiter PC, Wassen MJ. 2014. Low investment in sexual reproduction threatens plants adapted to phosphorus limitation. Nature 505: 82-86.

Giesler R, Hogberg M, Hogberg P. 1998. Soil chemistry and plants in Fennoscandian boreal forest as exemplified by a local gradient. Ecology 79: 119-137.

Giesler R, Petersson T, Hogberg P. 2002. Phosphorus limitation in boreal forests: Effects of aluminum and iron accumulation in the humus layer. Ecosystems 5: 300-314.

Grime JP, Hunt R. 1975. Relative growth-rate: its range and adaptive significance in a local flora. Journal of Ecology 63: 393-422.

Hoyle GL, Venn SE, Steadman KJ, Good RB, McAuliffe EJ, Williams $\mathrm{ER}$, Nicotra AB. 2013. Soil warming increases plant species richness but decreases germination from the alpine soil seed bank. Global Change Biology 19: 1549-1561.

Jackson MB, Armstrong W. 1999. Formation of aerenchyma and the processes of plant ventilation in relation to soil flooding and submergence. Plant Biology 1: 274-287.

Jansson R, Laudon H, Johansson E, Augspurger C. 2007. The importance of groundwater discharge for plant species number in riparian zones. Ecology 88: 131-139.

Kalbus E, Reinstorf F, Schirmer M. 2006. Measuring methods for groundwater-surface water interactions: a review. Hydrology and Earth System Sciences 10: 873-887.

Kattge J, Diaz S, Lavorel S, Prentice C, Leadley P, Bonisch G, Garnier E, Westoby M, Reich PB, Wright IJ, Cornelissen JHC, Violle C, Harrison SP, van Bodegom PM, Reichstein M, Enquist BJ, Soudzilovskaia NA, Ackerly DD, Anand M, Atkin O, Bahn M, Baker TR, Baldocchi D, Bekker R, Blanco CC, Blonder B, Bond WJ, Bradstock R, Bunker DE, Casanoves F, Cavender-Bares J, Chambers JQ, Chapin FS, Chave J, Coomes D, Cornwell WK, Craine JM, Dobrin BH, Duarte L, Durka W, Elser J, Esser G, Estiarte M, Fagan WF, Fang J, Fernandez-Mendez F, Fidelis A, Finegan B, Flores O, Ford H, Frank D, Freschet GT, Fyllas NM, Gallagher RV, Green WA, Gutierrez AG, Hickler T, Higgins SI, Hodgson JG, Jalili A, Jansen S, Joly CA, Kerkhoff AJ, Kirkup D, Kitajima K, Kleyer M, Klotz S, Knops JMH, Kramer K, Kuhn I, Kurokawa H, Laughlin D, Lee TD, Leishman M, Lens F, Lenz T, Lewis SL, Lloyd J, Llusia J, Louault F, Ma S, Mahecha MD, Manning P, 
Massad T, Medlyn BE, Messier J, Moles AT, Muller SC, Nadrowski K, Naeem S, Niinemets U, Nollert S, Nuske A, Ogaya R, Oleksyn J, Onipchenko VG, Onoda Y, Ordonez J, Overbeck G, Ozinga WA, Patino S, Paula S, Pausas JG, Penuelas J, Phillips OL, Pillar V, Poorter H, Poorter L, Poschlod P, Prinzing A, Proulx R, Rammig A, Reinsch S, Reu B, Sack L, Salgado-Negre B, Sardans J, Shiodera S, Shipley B, Siefert A, Sosinski E, Soussana JF, Swaine E, Swenson N, Thompson K, Thornton P, Waldram P, Weiher E, White M, White S, Wright SJ, Yguel B, Zaehle S, Zanne AE, Wirth C. 2011. TRY - a global database of plant traits. Global Change Biology 17: 2905-2935.

Keddy PA. 1992. Assembly and response rules: two goals for predictive community ecology. Journal of Vegetation Science 3: 157-164.

Kleyer M, Bekker RM, Knevel IC, Bakker JP, Thompson K, Sonnenschein M, Poschlod P, van Groenendael JM, Klimes L, Klimesova J, Klotz S, Rusch GM, Hermy M, Adriaens D, Boedeltje G, Bossuyt B, Dannemann A, Endels P, Goetzenberger L, Hodgson JG, Jackel AK, Kuehn I, Kunzmann D, Ozinga WA, Roemermann C, Stadler M, Schlegelmilch J, Steendam HJ, Tackenberg O, Wilmann B, Cornelissen JHC, Eriksson O, Garnier E, Peco B. 2008. The LEDA Traitbase: a database of life-history traits of the Northwest European flora. Journal of Ecology 96: 1266-1274.

Klijn F, Witte JPM. 1999. Eco-hydrology: Groundwater flow and site factors in plant ecology. Hydrogeology Journal 7: 65-77.

Klimešová J, de Bello F. 2009. CLO-PLA: the database of clonal and bud bank traits of Central European flora. Journal of Vegetation Science 20: 511-516.

Klotz S, Kühn I, Durka W. 2002. BIOLFLOR - Eine Datenbank zu biologisch-ökologischen Merkmalen der Gefäßpflanzen in Deutschland. Schriftenreihe für Vegetationskunde 38:Bonn: Bundesamt für Naturschutz.

Klove B, Ala-aho P, Bertrand G, Boukalova Z, Erturk A, Goldscheider N, Ilmonen J, Karakaya N, Kupfersberger H, Kvaerner J, Lundberg A, Mileusnic M, Moszczynska A, Muotka T, Preda E, Rossi P, Siergieiev D, Simek J, Wachniew P, Angheluta V, Widerlund A. 2011 Groundwater dependent ecosystems. Part I: hydroecological status and trends. Environmental Science \& Policy 14: 770-781.

Knops JMH, Reinhart A. 2000. Specific leaf area along a nitrogen fertilization gradient. American Midland Naturalist 144: 265-272.

Konings H, Koot E, Tijmandewolf A. 1989. Growth-characteristics, nutrient allocation and photosynthesis of Carex species from floating fens. Oecologia 80: 111-121.

Kuglerová L, Jansson R, Ågren A, Laudon H, Malm-Renöfält B. 2014. Groundwater discharge creates hotspots of riparian plant species richness in a boreal forest stream network. Ecology 95: 715-725.

Lambers H, Poorter H. 1992. Inherent variation in growth rate between higher plants: a search for physiological causes and ecological consequences. Advances in Ecological Research 23: 187-261.

Lamers LPM, van Diggelen JMH, Op den Camp HJM, Visser EJW, Lucassen ECHET, Vile MA, Jetten MSM, Smolders AJP, Roelofs JGM. 2012. Microbial transformations of nitrogen, sulfur, and iron dictate vegetation composition in wetlands: a review. Frontiers in Microbiology 3: 156-156.

Leibold MA, Holyoak M, Mouquet N, Amarasekare P, Chase JM, Hoopes MF, Holt RD, Shurin JB, Law R, Tilman D, Loreau M, Gonzalez A. 2004. The metacommunity concept: a framework for multi-scale community ecology. Ecology Letters 7: 601-613.

Leyer I. 2005. Predicting plant species' responses to river regulation: the role of water level fluctuations. Journal of Applied Ecology 42: 239-250.

Lucassen ECHET, Smolders AJP, Boedeltje G, van den Munckhof PJJ, Roelofs JGM. 2006. Groundwater input affecting plant distribution by controlling ammonium and iron availability. Journal of Vegetation Science 17: 425-434.

Marini L, Nascimbene J, Scotton M, Klimek S. 2008. Hydrochemistry, water table depth and related distribution patterns of vascular plants in a mixed mire. Plant Biosystems 142: 79-86.

McNamara JP, Siegel DI, Glaser PH, Beck RM. 1992. Hydrogeologic controls on peatland development in the Malloryville wetland, New York (USA). Journal of Hydrology 140: 279-296.

Moles AT, Falster DS, Leishman MR, Westoby M. 2004. Small-seeded species produce more seeds per square metre of canopy per year, but not per individual per lifetime. Journal of Ecology 92: 384-396.

Mongon J, Konnerup D, Colmer TD, Rerkasem B. 2014. Responses of rice to $\mathrm{Fe} 2+$ in aerated and stagnant conditions: growth, root porosity and radial oxygen loss barrier. Functional Plant Biology 41: 922-929.
Ordoñez JC, van Bodegom PM, Witte J-PM, Bartholomeus RP, van Dobben HF, Aerts R. 2010a. Leaf habit and woodiness regulate different leaf economy traits at a given nutrient supply. Ecology 91: 3218-3228.

Ordoñez JC, van Bodegom PM, Witte J-PM, Bartholomeus RP, van Hal JR, Aerts R. 2010b. Plant strategies in relation to resource supply in mesic to wet environments: does theory mirror nature? American Naturalist 175: 225-239.

Ordoñez JC, van Bodegom PM, Witte J-PM, Wright IJ, Reich PB, Aerts R. 2009. A global study of relationships between leaf traits, climate and soil measures of nutrient fertility. Global Ecology and Biogeography 18: $137-149$.

Ponnamperuma FN. 1972. The chemistry of submerged soils. Advances in Agronomy 24: 29-96.

Poorter H, Remkes C. 1990. Leaf area ratio and net assimilation rate of 24 wild species differing in relative growth rate. Oecologia 83: 553-559.

R Core Team. 2012. R: a language and environment for statistical computing. $R$ Foundation for Statistical Computing Vienna, Austria: http://www.r-project.org/ (accessed January 2012)

Raunkiær, C 1934. The Life Forms of Plants and Statistical Plant Geography.The Clarendon Press, Oxford.

Reich PB, Oleksyn J. 2004. Global patterns of plant leaf N and P in relation to temperature and latitude. Proceedings of the National Academy of Sciences of the United States of America 101: 11001-11006.

Roelofsen HD, van Bodegom PM, Kooistra L, Witte J-PM. 2014. Predicting leaf traits of herbaceous species from their spectral characteristics. Ecology and Evolution 4: 706-719.

Runhaar J, van 't Zelfde M, Groen CLG, Alkemade R. 2003. Bepaling ecotooptype en toetsing indeling in ecologische soortengroepen van vegetaties. RIVM rapport 999: 1-259.

Schaminée JHJ, Stortelder AHF, Weeda EJ. 1995a. De vegetatie van Nederland; deel 2: Plantgemeenschappen van Wateren, Moerassen en Natte Heiden. Opulus Press, Uppsala/Leiden.

Schaminée JHJ, Stortelder AHF, Weeda EJ. 1996. De vegetatie van Nederland; deel 3: Plantgemeenschappen van Graslanden, Zomen en Droge Heiden. Opulus press, Uppsala/Leiden.

Schaminée JHJ, Stortelder AHF, Westhoff V. 1995b. De vegetatie van Nederland; deel 1: Inleiding tot de Plantensociologie - Grondslagen, Methoden en Toepassingen. Opulus Press, Uppsala/Leiden.

Schaminée JHJ, Weeda EJ, Westhoff V. 1998. De vegetatie van Nederland; deel 4: Plantengemeenschappen van de Kust en van Binnenlandse Pioniermilieus. Opulus press, Uppsala/Leiden.

Snowden RED, Wheeler BD. 1993. Iron toxicity to fen plant species. Journal of Ecology 81: 35-46.

Stahl U, Kattge J, Reu B, Voigt W, Ogle K, Dickie J, Wirth C. 2013. Whole-plant trait spectra of North American woody plant species reflect fundamental ecological strategies. Ecosphere 4(10): 128. http://dx.doi. org/10.1890/ES13-00143.1

Suter M, Edwards PJ. 2013. Convergent succession of plant communities. is linked to species' functional traits. Perspectives in Plant Ecology Evolution and Systematics 15: 217-225.

Tahvanainen T. 2004. Water chemistry of mires in relation to the poor-rich vegetation gradient and contrasting geochemical zones of the northeastern Fennoscandian Shield. Folia Geobotanica 39: 353-369.

Valladares F, Matesanz S, Guilhaumon F, Araujo MB, Balaguer L, Benito-Garzon M, Cornwell W, Gianoli E, van Kleunen M, Naya DE, Nicotra AB, Poorter H, Zavala MA. 2014. The effects of phenotypic plasticity and local adaptation on forecasts of species range shifts under climate change. Ecology Letters 17: 1351-1364.

Van Bodegom PM, Sorrel BK, Oosthoek A, Aerts R. 2008. Separating the effects of partial submergence and soil oxygen demand on plant physiology. Ecology 89: 193-204.

Van der Meijden R. 1996. Heukels' FLORA van Nederland. WoltersNoordhoff Groningen: The Netherlands.

Van Mechelen C, Dutoit T, Kattge J, Hermy M. 2014. Plant trait analysis delivers an extensive list of potential green roof species for Mediterranean France. Ecological Engineering 67: 48-59.

Verheijen LM, Brovkin V, Aerts R, Boenisch G, Cornelissen JHC, Kattge J, Reich PB, Wright IJ, van Bodegom PM. 2013. Impacts of trait variation through observed trait-climate relationships on performance of an Earth system model: a conceptual analysis. Biogeosciences 10: $5497-5515$. 
Violle C, Navas M-L, Vile D, Kazakou E, Fortunel C, Hummel I, Garnier E. 2007. Let the concept of trait be functional!. Oikos 116: 882-892.

Wassen MJ, Barendregt A, Palczynski A, Desmidt JT, Demars H. 1990. The relationship between fen vegetation gradients, groundwater-flow and flooding in an undrained valley mire at Biebrza, Poland. Journal of Ecology 78: 1106-1122.

Weeda EJ, Schaminée JHJ, Van Duuren L. 2000. Atlas van Plantgemeenschappen in Nederland Deel 1: Wateren, Moerassen en Natte Heiden. KNNV Uitgeverij, Utrecht.

Weeda EJ, Schaminée JHJ, Van Duuren L. 2002. Atlas van Plantgemeenschappen in Nederland Deel 2: Graslanden, Zomen en Droge Heiden. KNNV Uitgeverij, Utrecht.

Weeda EJ, Schaminée JHJ, Van Duuren L. 2003. Atlas van Plantgemeenschappen in Nederland Deel 3: Kust en Binnenlandse Pioniermilieus. KNNV Uitgeverij, Utrecht.

Weeda EJ, Schaminée JHJ, van Duuren L. 2005. Atlas van Plantengemeenschappen van Nederland Deel 4: Bossen, Struwelen en Ruigten. KNNV Uitgeverij, Utrecht.

Weeda EJ, Westra R, Westra C, Westra T. 1999. Nederlands Oecologische FLORA Wilde Planten en Hun Relaties Deel 1-5. IVN/VARA/ VEWIN/KNNV Uitgeverij.

Whittaker RH, Levin SA, Root RB. 1973. Niche, habitat, and ecotope. American Naturalist 107: 321-338.

Wilson SD, Tilman D. 1993. Plant competition and resource availability in response to disturbance and fertilization. Ecology 74: 599-611.

Witte J-PM, Wójcik RB, Torfs PJJF, de Haan MWH, Hennekens S. 2007. Bayesian classification of vegetation types with Gaussian mixture density fitting to indicator values. Journal of Vegetation Science 18: 605-612.

Wright IJ, Reich PB, Westoby M, Ackerly DD, Baruch Z, Bongers F, Cavender-Bares J, Chapin T, Cornelissen JHC, Diemer M, Flexas J, Garnier E, Groom PK, Gulias J, Hikosaka K, Lamont BB, Lee T, Lee W, Lusk C, Midgley JJ, Navas ML, Niinemets U, Oleksyn J, Osada N, Poorter H, Poot P, Prior L, Pyankov VI, Roumet C, Thomas SC, Tjoelker MG, Veneklaas EJ, Villar R. 2004. The worldwide leaf economics spectrum. Nature 428: 821-827.

Zimmer MA, Bailey SW, McGuire KJ, Bullen TD. 2013. Fine scale variations of surface water chemistry in an ephemeral to perennial drainage network. Hydrological Processes 27: 3438-3451.

Zinko U, Dynesius M, Nilsson C, Seibert J. 2006. The role of soil pH in linking groundwater flow and plant species density in boreal forest landscapes. Ecography 29: 515-524.

Zinko U, Seibert J, Dynesius M, Nilsson C. 2005. Plant species numbers predicted by a topography-based groundwater flow index. Ecosystems 8: $430-441$.

Zou Y, Wang G, Grace M, Lou X, Yu X, Lu X. 2014. Response of two dominant boreal freshwater wetland plants to manipulated warming and altered precipitation. PloS One 9: e104454-e104454.

\section{SUPPORTING INFORMATION}

Additional supporting information may be found in the online version of this article at the publisher's web site. 